\title{
RNA Metabolism in Primary Cultures of Xenopus laevis Kidney Cells. II. Comparison of the Pattern of RNA Synthesis at Different Phases of Growth
}

\author{
Koichiro Shiokawa, Yoshio Misumi, Yuko Nishio and Kiyotaka Yamana \\ Department of Biology, Faculty of Science, Kyushu University, Fukuoka, 812, \\ Japan
}

\begin{abstract}
The incorporation pattern of ${ }^{3} \mathrm{H}$-uridine into various RNA species was examined at the lag, logarithmic and stationary phases in primary cultures of Xenopus laevis kidney cells. The relative amount of labeling of $40 \mathrm{~S}$ ribosomal RNA precursor was strikingly high in stationary phase cells. It was suggested that in addition to the transcription rate of ribosomal RNA genes, the processing rate of the ribosomal RNA precursor may be reduced when cellular proliferation becomes inactive at the stationary phase.
\end{abstract}

It is well known that ribosomal RNA synthesis is closely correlated to the rate of cellular proliferation. However, the mechanism by which such regulation is realized is still unclear $(1,2,3,4,5,10)$. In the present paper, the pattern of RNA synthesis was compared at different growth phases of primary cultures of Xenopus laevis kidney cells (8). It was observed that the proportion of labeling of $40 \mathrm{~S}$ ribosomal RNA precursor to that of $18 \mathrm{~S}$ and $28 \mathrm{~S}$ mature ribosomal RNA increased remarkably when the logarithmic phase cells entered the stationary phase. Thus, it is possible that the processing rate of this RNA species is reduced at this phase of growth.

\section{MATERIALS AND METHODS}

Primary kidney cells of Xenopus laevis were prepared as described by Misumi et al. (8). Cells were grown in $75 \%$ Eagle's minimal essential medium (MEM) supplemented with $10 \%$ fetal calf serum to which 100 units $/ \mathrm{ml}$ of penicillin, $50 \mu \mathrm{g} / \mathrm{ml}$ of streptomycin and $20 \mu \mathrm{g} / \mathrm{ml}$ of n-butyl-p-hydroxybenzoate were added (9). At day 3 of culture, unattached cells were removed by exchanging the culture medium with fresh medium.

For analysis of the pattern of RNA synthesis, cells were grown in glass tubes and labeled with ${ }^{3} \mathrm{H}$-uridine at different phases of growth. For pulse-chase experiments, cells were grown in plaque bottles and labeled with (methyl- ${ }^{3} \mathrm{H}$ )-methionine in methionine-free $75 \%$ Eagle's MEM and then chased in the presence of actinomycin $\mathrm{D}$ and non-radioactive methionine. The labeled cells were homogenized in $0.1 \mathrm{M}$ sodium acetate, $\mathrm{pH} 5.0$, which contained $0.5 \%$ sodium dodecyl sulfate and $1 \mathrm{mg} / \mathrm{ml}$ bentonite, and then treated successively with phenol and chloroform-phenol (1:1). The RNA was purified, fractionated on $0.5 \%$ agarose $-2.2 \%$ polyacrylamide gel, and the radioactivity was counted in a Beckman scintillation spectrometer in Triton-toluene-2, 5-diphenyloxazole, as described previously (8). 


\section{RESULTS AND DISCUSSION}

When RNA labeled for $1 \mathrm{~h}$ periods at the lag, logarithmic and stationary phases was analyzed on polyacrylamide gels, four distinct radioactivity peaks (40, 28, 18 and 4S) and some heterogeneously distributed RNA were evident in the profiles (Fig. 1). The amount of the label incorporation into total RNA was relatively high at the lag phase, increased slightly at the logarithmic phase and decreased greatly at the stationary phase. These observations are consistent with our previous results (8). The labeling pattern was quite similar between the lag and logarithmic phases. These observations suggest that the activation of RNA synthesis already occurred prior to the commencement of rapid cellular proliferation, as in the case of primary cultured rabbit kidney cells (7). In contrast, the pattern of RNA synthesis differed considerably in stationary phase cells from lag phase or logarithmic phase cells, in that stationary phase cells contained a very large amount of radioactivity in $40 \mathrm{~S}$ RNA as compared with $18 \mathrm{~S}$ and $28 \mathrm{~S}$ ribosomal RNA. When the ratios of label incorporation into $18 \mathrm{~S}+28 \mathrm{~S}$ ribosomal RNA and into $4 \mathrm{~S}$ RNA were compared, the value was much lower in the stationary (0.6) than in the lag (1.3) or logarithmic phase cells
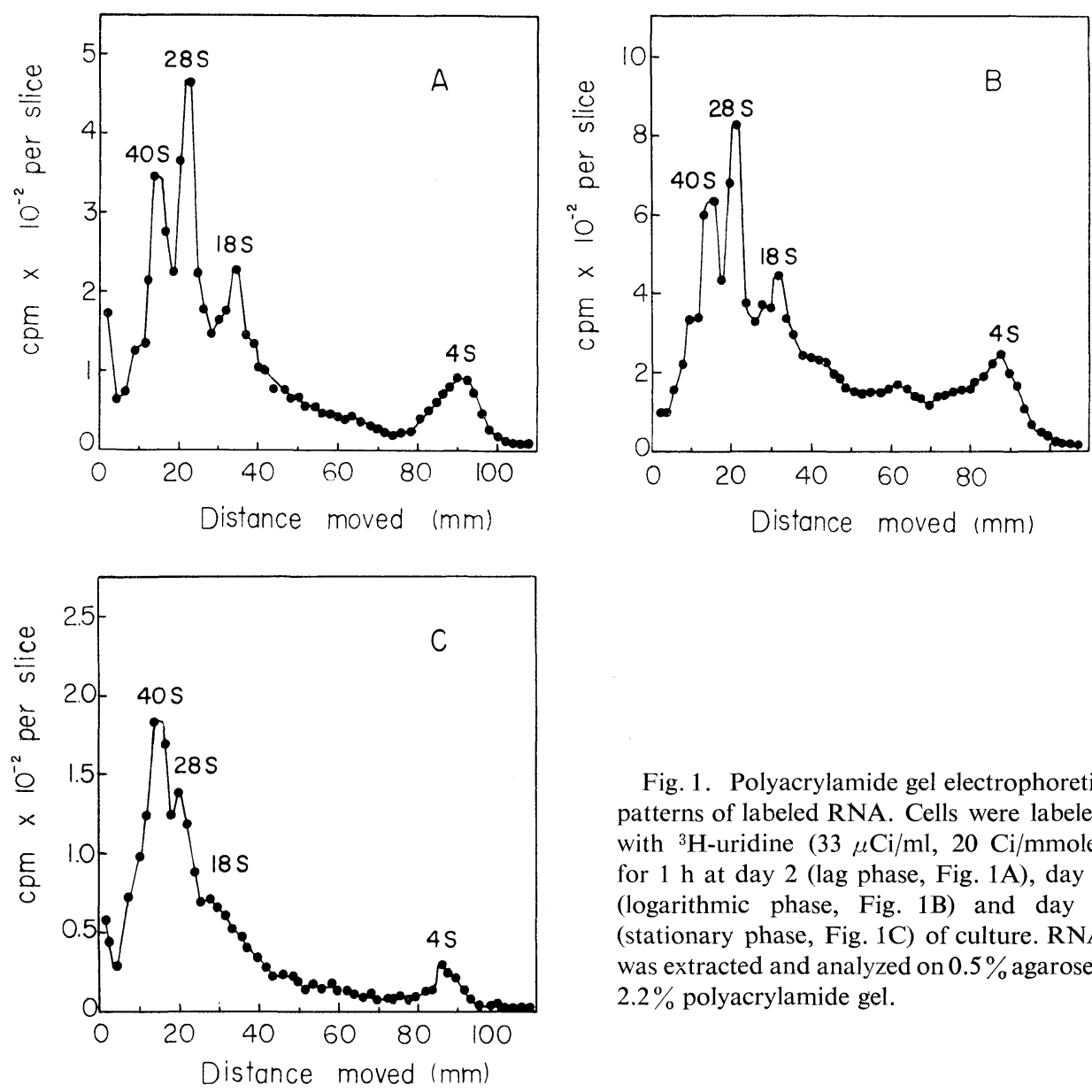

Fig. 1. Polyacrylamide gel electrophoretic patterns of labeled RNA. Cells were labeled with ${ }^{3} \mathrm{H}$-uridine $(33 \mu \mathrm{Ci} / \mathrm{ml}, 20 \mathrm{Ci} / \mathrm{mmole})$ for $1 \mathrm{~h}$ at day 2 (lag phase, Fig. 1A), day 4 (logarithmic phase, Fig. 1B) and day 8 (stationary phase, Fig. 1C) of culture. RNA was extracted and analyzed on $0.5 \%$ agarose$2.2 \%$ polyacrylamide gel. 
(1.7). Therefore, the results in Fig. 1 may also indicate that the accumulation of $18 \mathrm{~S}$ and 28S ribosomal RNA may be lower in stationary phase cells than in other growth phases. When cells were labeled for $5 \mathrm{~h}$, the peak of 40S RNA disappeared from the RNA profiles of the lag and logarithmic phase cells, but not from RNA of the stationary phase cells.

The nature of the 40S RNA component was studied by pulse-chase experiments using (methyl- $\left.{ }^{3} \mathrm{H}\right)$-methionine as label. The results obtained showed that the $40 \mathrm{~S}$ component was extensively methylated and, furthermore, chased into $18 \mathrm{~S}+28 \mathrm{~S}$ mature ribosomal RNA quantitatively. These results which were consistent with those of Landesman and Gross (6) permit us to conclude that the 40S component was a precursor to ribosomal RNA.

In our previous paper, we followed ${ }^{3} \mathrm{H}$-uridine uptake and incorporation during the growth cycle of Xenopus kidney cells and obtained results which suggested that cellular RNA synthesis became considerably inactivated at the stationary phase (8). The present paper compared the pattern of RNA synthesis in the three different phases of growth, and it was found that the relative labeling of 40S ribosomal RNA precursor increased greatly when cellular proliferation was reduced at the stationary phase. As has been suggested in our previous paper (8) and is generally known in other cultured cell systems $(3,4,10)$, the transcription of 40 S ribosomal RNA precursor may be repressed rather than being activated when cells become contact-inhibited at the stationary phase of growth. Furthermore, it is highly unlikely that the relative instability of $18 \mathrm{~S}$ and $28 \mathrm{~S}$ ribosomal RNA in stationary phase cells $(1,2,5,10)$ could bring about a significant lowering of the amount of labeled $18 \mathrm{~S}$ and $28 \mathrm{~S}$ ribosomal RNA, since it is known that mature ribosomal RNA is quite stable at least shortly after labeling. Based on these considerations, one plausible explanation of the present finding may be a reduction in the rate of processing of the ribosomal RNA precursor. The possibility of the regulation of ribosomal RNA production at the processing step in quiescent cells has not been studied extensively as a possible mechanism of cellular growth control. A more detailed study of the present system is now in progress.

Acknowledgments. The authors thank Dr. H. Okano, Kyushu Cancer Center Research Institute, and Dr. Y. Oka, Virus Research Laboratory, Takeda Chemical Industries, Osaka, for their help in developing the tissue culture system. Thanks are also due to Professor M. Amano, Hiroshima University, for helpful suggestions. This work was supported in part by a grant from the Ministry of Education of Japan.

\section{REFERENCES}

1. Abelson, H.T., L.F. Johnson, S. Penman and H. Green. Changes in RNA in relation to growth of the fibroblast. II. The lifetime of mRNA, rRNA and tRNA in resting and growing cells. Cell 1, 161-165, 1974

2. CoOper, H.L. Control of synthesis and wastage of ribosomal RNA in lymphocytes. Nature 227, 1105-1107, 1970

3. EMERSON, C.P. Regulation of the synthesis and the stability of ribosomal RNA during contact inhibition of growth. Nature New Biol. 232, 101-106, 1971

4. HoriuChI, R., Y. YAOI and M. AmANO. RNA synthesis in cultured chick embryo cells in growing and confluent phases. Dev. Growth Differ. 14, 185-195, 1972

5. Kolodny, G.M. Turnover of ribosomal RNA in mouse fibroblasts (3T3) in culture. Exp. Cell Res. 91, 101-106, 1975 
6. Landesman, R. and P.R. Gross. Pattern of macromolecule synthesis during development of Xenopus laevis. II. Identification of the 40 S precursor to ribosomal RNA. Dev. Biol. 19, 244 260, 1969

7. Lieberman, I., R. Abrams and P. Ove. Changes in the metabolism of ribonucleic acid preceeding the synthesis of deoxyribonucleic acid in mammalian cells cultured from the animal. J. Biol. Chem. 238, 2141-2149, 1963

8. Misumi, Y., S. Kurata, B. Sakaguchi, K. Shiokawa and K. Yamana. RNA metabolism in primary cultures of Xenopus laevis kidney cells. I. Characterization of growth phases and changes in number and size of nucleoli. Cell Struct. Funct. 1, 337-344, 1976

9. SHIOKAWA, K. and H. YAOI. Effects of sonication on physicochemical and biological properties of synthetic double-stranded polyribonucleotides as interferon inducer. Arch. Gesamte Virusforsch. 38, 109-124, 1972

10. Weber, M. J. Ribosomal RNA turnover in contact inhibited cells. Nature New Biol. 235, 5861,1972 